\title{
Isolasi dan Karakterisasi Protein 100kDa dari Membran Kepala Spermatozoa Kambing
}

\author{
Bayyinatul Muchtaromah $^{1 *}$, Sutiman B. Sumitro ${ }^{2}$, Soemarno ${ }^{3}$, Trini Susilawati $^{4}$ \\ ${ }^{1}$ Fakultas Sains dan Teknologi, Universitas Islam Negeri Malang \\ ${ }^{2}$ Fakultas Matematika dan Ilmu Pengetahuan Alam, Universitas Brawijaya \\ ${ }^{3}$ Fakultas Kedokteran, Universitas Brawijaya \\ ${ }^{4}$ Fakultas Peternakan, Universitas Brawijaya
}

\begin{abstract}
Abstrak
Antigen adalah protein yang dapat menginduksi terbentuknya antibodi. Berat molekul protein sebesar $100 \mathrm{kDa}$ dapat bertindak sebagai imunogen yang kuat. Tujuan dari penelitian ini adalah untuk mencari kandidat vaksin imunokontrasepsi dan melakukan isolasi serta karakterisasi protein 100 kDa yang diduga mempunyai peranan penting di dalam interaksi spermatozoa-ovum. Penelitian ini merupakan penelitian eksploratif. Materi Protein $100 \mathrm{kDa}$ diisolasi dari membran spermatozoa kambing menggunakan detergen $\mathrm{N}$-Octyl-glycopiranoside kemudian dirunning menggunakan metode SDS-PAGE dan dikoleksi dengan elektroelusi. Karakterisasi Protein 100 kDa meliputi penentuan berat molekul melalui SDS-PAGE, penentuan titik isoelektrik (pI) dengan IEF (isoelectric focusing) dan kandungan protein dengan metode Biuret. Hasil running isolat protein membran spermatozoa kambing menggunakan metode SDS-PAGE diperoleh pita protein yang terdiri atas 7 pita dengan berat molekul 166,7;122;100;82,8; 60,4; 29,9 dan 14,8 kDa. Isolat Protein $100 \mathrm{kDa}$ diperoleh dengan purifikasi menggunakan metode elektroelusi. Hasil IEF gel elektroforesis Protein $100 \mathrm{kDa}$ dari membran spermatozoa kambing yang diejakulasikan ini mempunyai tiga titik isoelektrik yaitu 6,37; 6,05 dan 5,64. Kandungan protein dalam isolat Protein $100 \mathrm{kDa}$ sebesar $2375 \pm 5,65$ $\mu \mathrm{g} / \mathrm{mL}$. Hasil ini menunjukkan bahwa isolat protein $100 \mathrm{kDa}$ dapat digunakan sebagai imunogen.
\end{abstract}

Kata Kunci : isolasi, karakterisasi, membrane spermatozoa, protein $100 \mathrm{kDa}$

\section{PENDAHULUAN}

Dari hasil penelitian yang dilakukan oleh Mitra et al. [1] diketahui bahwa membran plasma spermatozoa kambing memiliki aktivitas enzim ecto-cAMP independent protein kinase (ecto-CIK) yang menyebabkan fosforilasi dari protein endogenous (fosfoprotein). Substrat dari enzim ecto-CIK (MPS ecto-CIK), berhasil diisolasi oleh Maiti et al. [2] dengan menggunakan enzim kinase endogen $\left[\mathrm{\gamma}^{32} \mathrm{P}\right]-\mathrm{ATP}$ dari membran plasma spermatozoa kambing di cauda epididimis. Untuk melarutkan ${ }^{32}$ P-labeled substrat diperlakukan dengan Triton X-100 1\% kemudian dimasukkan Sepacryl S-300 molecular sieve chromatography. Dari perlakuan tersebut berhasil ditemukan tiga titik isoelektrik MPS ectoCIK yaitu 6,37; 6,05 dan 5,14.

Dengan menggunakan Sepacryl S-200 diketahui bahwa MPS ecto-CIK merupakan

\footnotetext{
* Alamat korespondensi:

Bayyinatul Muchtaromah

Email: Bayyinatul_m@yahoo.com

Alamat : Fakultas Sains dan Teknologi UIN Malang
}

fosfoprotein monomer dengan berat molekul 100 $\mathrm{kDa}$, hasil yang sama juga didapatkan dengan menggunakan elektroforesis SDS PAGE. Fosfoprotein hasil isolasi membran plasma spermatozoa cauda epididimis ini menunjukkan tingkat kemurnian yang tinggi seperti yang ditunjukkan pada band protein tunggal (monomer) di bawah kondisi native dan denaturing gel [2].

Analisis Western Blot terhadap tiga isoform protein MPS ecto-CIK yang mempunyai harga $\mathrm{pl}$ (point isoelectric) berbeda memperlihatkan bahwa ketiga isoform tersebut berikatan dengan anti MPS ecto-CIK [2].

Pada penelitian pendahuluan telah diisolasi protein dengan berat molekul (BM) 100 kDa dari membran kepala spermatozoa kambing yang sudah diejakulasikan. Antigen adalah protein yang dapat menginduksi terbentuknya antibodi. Timbulnya antibodi dapat digunakan sebagai petunjuk bahwa protein yang dimaksud mempunyai sifat imunogenik. Berat molekul protein sebesar $100 \mathrm{kDa}$ dapat bertindak sebagai imunogen yang kuat. Subowo [3] mengatakan 
protein dengan berat molekul lebih dari 10 kilo dalton merupakan imunogen kuat. Oleh karena itu, penelitian ini ini dilakukan untuk mencari bahan kandidat vaksin imunokontrasepsi sehingga perlu dilakukan isolasi dan karakterisasi protein $100 \mathrm{kDa}$ tersebut.

\section{METODE PENELITIAN \\ Variabel Penelitian}

Parameter yang diamati untuk karakterisasi Protein 100 kDa dari membran spermatozoa kambing yang sudah diejakulasikan meliputi berat molekul, penentuan titik isoelektrik dan kandungan protein.

Spermatozoa yang dipakai dalam penelitian ini berasal dari semen yang ditampung dari kambing yang berumur 1,5-2 tahun, berat badan $\pm 50 \mathrm{~kg}$ dengan kondisi sehat.

Untuk mengetahui karakter biokimiawi protein $100 \mathrm{kDa}$ dari membran kepala spermatozoa kambing yang sudah diejakulasikan dilakukan elektroforesis SDS PAGE untuk menentukan berat molekulnya. Isoelectric Focusing (IEF) untuk menentukam titik isoelektriknya dan metode Biuret untuk mengukur kandungan proteinnya.

Bahan-bahan yang digunakan pada penelitian tahap I ini adalah: semen kambing peranakan etawah (PE) umur 1,5-2 tahun yang dipelihara oleh peternak desa Sumber Sekar, vaselin, air hangat, $\mathrm{NaCl}$ fisiologis 0,9\%, eosin negrosin, Brackett and Oliphant's Medium ( $\mathrm{NaCl}, \mathrm{KCl}, \mathrm{CaCl}_{2}$, $\mathrm{NaH}_{2} \mathrm{PO}_{4}, \mathrm{MgCl}_{2}, \mathrm{NaHCO}_{3}$, Glukosa, Sodium piruvat, Penisilin (Meiji), Streptomisin (Meiji), Phenol red, PBS Dulbecoes, $\mathrm{NaCl} 3 \%$, aprotinin, leupeptin, pepstatin, phenyl methyl sulfonil fluoride (PMSF), N-Octyl-Glycopiranoside (NOG), akuades steril, sodium azida (sigma), buffer trisglisin, buffer fosfat, bis akrilamid, poliakrilamid, sodium dedosil sulfat (SDS), methanol $15 \%$, asam asetat glacial 3\% (Merck), 8-mercaptoetanol, Phosfet Buffer Salin, $\mathrm{NaHCO}_{3}$, alkohol 70\%, Teepol 1\%, Tris base, Tween 20, glycine, etanol (Merck), bromophenol blue, Reducing Sample Buffer (RSB), membran nitroselulose, urea, akrilamid 30\%, bisakrilamid 0,2\%, ampholine $\mathrm{pH}$ 3,5-10, ampholine $\mathrm{pH} 4-6$, APS 10\%, Amonium persulfat (APS), $N, N, N^{\prime}, \quad N^{\prime}$ tetrametiletilen diamina (TEMED), TCA 10\%, TCA 1\%, $\mathrm{KCl} 10 \mathrm{mM}$, $\mathrm{CuSO}_{4} .5 \mathrm{H}_{2} \mathrm{O}$, $\mathrm{NaKC}_{4} \mathrm{O}_{6} 4 \mathrm{H}_{2} \mathrm{O}$, Bovine Serum Albumin (BSA).

Alat yang digunakan adalah satu unit vagina buatan, mikroskop cahaya, gelas obyek, cover glass, ose, haemositometer thoma, handly counter, kertas lakmus, kertas tissue, seperangkat alat gelas, timer, eppendorf, tip, sonication bath, homogenizer, magnetic stirrer, tabung sentrifuse, sentrifuse tipe T-C kecepatan maks 5000 rpm, sentrifuse dingin merk Jovan MR 1822 (maks $18000 \mathrm{rpm}$ ), neraca analitik merk Mettler AE-50, mini 2D elektroforesis proteon II (Biorad), spektrofotometer UV-VIS Thermo Spectronic Genesys 10 UV, waterbath, vorteks, pipet mikro 10-1000 $\mu \mathrm{l}$, pipet mikro $10 \mu \mathrm{l}$, pipet mikro $20 \mu \mathrm{l}, \mathrm{pH}$ meter, shaker, water bath dan inkubator $\mathrm{CO}_{2}$.

\section{Penampungan Semen Kambing}

Penampungan semen pada kambing jantan dilakukan dengan menggunakan vagina buatan. Pejantan yang akan ditampung dipersiapkan dengan membersihkan preputium dengan air kemudian dikeringkan. Vagina buatan yang telah dilengkapi dengan tabung penampung semen diisi dengan air hangat sampai mendapatkan suhu kira-kira $40^{\circ} \mathrm{C}$ dan sepertiga bagian depan selubung diberi vaselin. Penampungan semen dilakukan setelah 3-5 kali false mounting dan semen ejakulat pertama ditampung untuk diperiksa [4].

\section{Uji Kualitas Semen Segar}

Pemeriksaan kualitas meliputi pemeriksaan secara makroskopis dan mikroskopis merujuk pada Partodihardjo [4]. Pemeriksaan secara makroskopis meliputi: volume, warna, $\mathrm{pH}$ serta uji kekentalan atau konsistensi. Volume diukur dengan melihat langsung pada tabung berskala, warna dilihat langsung pada tabung penampung, $\mathrm{pH}$ diukur dengan menggunakan kertas lakmus yang kemudian dicocokkan dengan warna standar pada $\mathrm{pH}$ pen. Konsistensi diperiksa dengan menggoyangkan tabung berisi semen secara perlahan.

Pemeriksaan mikroskopis yang meliputi persentase motilitas, dengan melihat persentase motilitas individu, motilitas massa, uji viabilitas dan konsentrasi spermatozoa. Penentuan persentase motilitas spermatozoa dilakukan dengan melihat gerakan individu spermatozoa, yang diperiksa menggunakan mikroskop dengan pembesaran $400 \mathrm{x}$. Penilaian dilakukan dengan menghitung 100 spermatozoa yang bergerak aktif maju ke depan (gerakan maju progressif) dan dipersentasekan.

Motilitas massa dengan melihat gerakan spermatozoa yang berupa gelombang, dengan pembesaran $100 \mathrm{x}$. Penilaian sangat baik $(+++)$ bila terlihat gelombang besar, banyak, gelap, jelas dan bergerak cepat, baik (++) bila terlihat 
gelombang kecil, tipis, jarang, kurang jelas dan bergerak lamban; sedang (+) bila terlihat gerak individu aktif progresif dan buruk; (0) tidak ada gerakan sama sekali.

Uji viabilitas spermatozoa dilakukan dengan pewarnaan eosin negrosin. Spermatozoa yang hidup tidak menyerap warna, sedangkan yang mati menyerap warna. Pengamatan menggunakan mikroskop cahaya dengan pembesaran 100x, dihitung sebanyak 100 spermatozoa, sehingga dapat diketahui proporsi spermatozoa yang hidup dan yang mati.

Pemeriksaan konsentrasi spermatozoa dilakukan menggunakan haemocytometer. Dengan cara pipet eritrosit yang berskala 0,5101 dihubungkan dengan selang penghisap. Semen dihisap hingga skala 0,5 lalu diteruskan dengan $\mathrm{NaCl}$ fisiologis sampai pada skala 101. Setelah itu digoyang dengan gerakan menyerupai angka 8 selama 2-3 menit. Pada saat akan dilakukan perhitungan, beberapa tetes dibuang dan dikocok lagi. Selanjutnya "kamar hitung Neubauer" yang sudah dipasangi cover glass ditetesi isi pipet eritrosit. Kemudian gelas penutup ditekan perlahan. Perhitungan konsentrasi dengan menghitung lima kotak besar secara diagonal di bawah mikroskop dengan pembesaran 400x.

\section{Isolasi membran kepala spermatozoa kambing}

Metode Isolasi ini merupakan metode modifikasi dari Jayendran et al. [5], Hinsch et al. [6] dan Gatti et al. [7]. Mula-mula spermatozoa diperkaya dan dimurnikan dari sel yang lain dengan metode Swim Up. Satu $\mathrm{ml}$ semen diencerkan dengan PBS dulbecoes 1:5 diikuti dengan sentrifugasi pada $2000 \mathrm{rpm}$ selama 10 menit sebanyak 2 kali pada suhu kamar untuk pencucian terhadap seminal plasma.

Medium Brackett Olliphant $(2 \mathrm{ml})$ secara hatihati diletakkan pada pelet, dengan memiringkan dinding tabung sudut $45^{\circ} \mathrm{C}$ dan diinkubasi selama 20 menit pada $37^{\circ} \mathrm{C}$. Supernatan mengandung fraksi spermatozoa motil yang diperkaya diaspirasi dan disentrifugasi selama 10 menit dengan kecepatan $3500 \mathrm{rpm}$ pada suhu kamar. Ditambahkan PMSF 0,5 mM, leupeptin $4 \mu \mathrm{g} / \mathrm{ml}$, aprotinin $4 \mu \mathrm{g} / \mathrm{ml}$, pepstatin $1 \mu \mathrm{g} / \mathrm{ml}$ divorteks selama 5 menit, tiap 1 menit dimasukkan refrigerator. Kemudian ditambahkan detergen $\mathrm{N}$ Octyl-Glycopiranoside 1\%, divorteks, kemudian dihomogenizer selama 3 menit pada suhu $4^{\circ} \mathrm{C}$ setelah itu disonikasi dalam sonication bath selama 3 menit.
Suspensi didiamkan dalam refrigerator selama 30 menit dan disentrifuse $12.000 \mathrm{rpm}$ selama 10 menit pada suhu $4^{\circ} \mathrm{C}$ sebanyak $2 x$. Supernatan diambil kemudian dilakukan dialisis semalam dalam PBS. Hasilnya dapat langsung digunakan untuk elektroforesis atau ditambahkan etanol (1:1) dan didiamkan semalam dalam refrigerator. Kemudian disentrifuse 6000 rpm selama 10 menit kemudian taruh di freezer selama 5 menit, supernatan dibuang dan pelet diangin-anginkan. Jika sudah tidak berbau ditambahkan tris $\mathrm{Cl} 20 \mathrm{mM}$ dan disimpan pada suhu $-40^{\circ} \mathrm{C}$.

\section{Penentuan Berat Molekul \\ Persiapan gel}

Plat gel dibuat dengan merangkai dua plat kaca dengan jarak antar plat $\pm 1 \mathrm{~mm}$. Gel dibuat dua lapis yaitu gel sebagai tempat sampel (stacking gel) dan gel sebagai media untuk pemisahan protein (separating gel).

Separating gel dibuat dengan mencampurkan semua bahan kecuali ammonium persulfat (APS) dan $N, N, N^{\prime}, N^{\prime}$ tetrametiletilen diamina (TEMED), kemudian didegas selama 10 menit. APS dan TEMED ditambahkan, dikocok sebentar kemudian dimasukkan dalam plate dan dibiarkan 10-30 menit sampai gel mengeras. Stacking gel dibuat dengan cara yang sama tanpa didegas dan setelah separating gel mengeras, larutan stacking gel dituangkan di atasnya dan dipasang sisiran sampai gel mengeras dan terbentuk sumuran. Plate dipasang pada alat elektroforesis set mini protein gel, dan running buffer dituangkan pada alat tersebut.

\section{Injeksi Sampel}

Sampel yang berisi $12,5 \mu \mathrm{l}$ isolat protein membran spermatozoa dan $12,5 \mu \mathrm{l}$ reducing sample buffer (RSB) dipanaskan dalam penangas air bersuhu $100^{\circ} \mathrm{C}$ selama 2 menit, setelah didinginkan sampel siap dimasukkan dalam sumur-sumur gel dengan volume $10 \mu$ untuk tiap sumur. Untuk protein standar diperlakukan sama. Setelah itu anoda dihubungkan dengan reservoir bagian bawah dan katoda dihubungkan dengan reservoir bagian atas. Power supply dihubungkan dengan listrik menggunakan arus sebesar 30 mA 600 volt selama 2-3 jam. Proses pemisahan dihentikan setelah warna biru penanda $\pm 0,5 \mathrm{~cm}$ dari batas bawah plate gel.

\section{Perlakuan setelah running}

Gel hasil running direndam dalam larutan staining sambil digoyang selama 30 menit. 
Kemudian dicuci dengan $150 \mathrm{~mL}$ asam asetat yang direndam dalam larutan destaining selama 30 menit sambil digoyang. Selanjutnya dicuci dengan asam asetat sampai bening.

Penentuan massa molekul relatif ( $\mathrm{Mr}$ ) protein dilakukan dengan bantuan protein standar. Untuk menentukan berat molekul protein, dilakukan dengan menghitung Rf (Retardation factor) dari masing-masing pita menggunakan rumus:

$\mathrm{Rf}=$ Jarak pergerakan pita dari tempat awal Jarak pergerakan warna dari tempat awal

Selanjutnya dibuat kurva standar dari protein standar sehingga dari kurva ini didapatkan persamaan reaksi dan ditentukan massa molekul relatif sampel.

Tabel 1. Nilai Protein Standar Produksi Biorad

\begin{tabular}{cc}
\hline $\mathbf{R f}(\mathbf{S b} \mathbf{X})$ & $\mathbf{B M} \mathbf{( k D a )}$ \\
\hline 0,064 & 200 \\
0,177 & 116,25 \\
0,223 & 97,4 \\
0,371 & 66,2 \\
0,564 & 45 \\
0,887 & 31 \\
\hline
\end{tabular}

Isolasi dan Purifikasi Protein 100 kDa dengan Metode Elektroelusi

Gel hasil SDS-PAGE (gel akrilamid) yang tidak diwarnai dipotong sepanjang pita yang sudah ditentukan berada pada BM 100 kDa. Masingmasing potongan gel dimasukkan ke dalam kantong selofan dan direndam dengan 0,2 $\mathrm{mM}$ phosphat buffer (PB) sebanyak 1-2 ml. Kemudian dimasukkan dalam chamber elektroelusi yang mengandung phosphat buffer 0,1 mM. Langkah berikutnya dilakukan elektroelusi di dalam cool chamber $40^{\circ} \mathrm{C}$ (dalam refrigerator), power supply dinyalakan dengan kekuatan $220 \mathrm{~V}, 20 \mathrm{~mA}$ selama overnight.

Protein yang sudah terelusi dapat ditentukan dengan cara mewarnai potongan gel acrilamide dengan staining commasie blue selama 20 menit. Kemudian ditambahkan destaining, bila tidak terdapat pita berarti protein sudah terelusi. Selanjutnya cairan yang mengandung protein yang terdapat dalam kantong selofan dikeluarkan kemudian dipresipitasi dan dipurifikasi dengan ethanol absolut 1:1 untuk mendapatkan protein yang dimaksud.

\section{Penentuan Titik Isoelektrik}

Membuat Akrilamid 31\%

Akrilamid sebanyak $3 \mathrm{gr}$ dan bis akrilamid 0,1

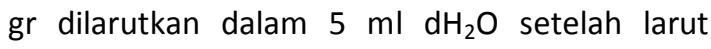
ditambahkan $\mathrm{dH}_{2} \mathrm{O}$ sampai $10 \mathrm{~mL}$.

\section{Membuat Gel}

Urea sebanyak $5 \mathrm{gr}$ dan $3,5 \mathrm{dH}_{2} \mathrm{O}$ dilarutkan terlebih dahulu sambil dipanaskan. Setelah larut dipindah ke tabung polipropilen $45 \mathrm{~mL}$. Masingmasing bahan yaitu Akrilamid 31\%, Ampholite pH 3-10 sebanyak $40 \mu \mathrm{L}, 200 \mu \mathrm{L}$ ampholite $\mathrm{pH}$ 5-7, 20,7 $\mu \mathrm{L}$ APS 10\%,16,4 $\mu \mathrm{L}$ TEMED ditambahkan satu per satu dan divorteks. Setelah semua bahan larut dan tercampur rata kemudian dimasukkan ke plate sampai penuh dan dipasang sisir, ditunggu sampai ngejel lebih kurang 1,5 jam.

Running

Memasang plate yang berisi gel. Chatolyte dituang pada upper buffer plate (kutub -), sedang anolyte dituang pada lower buffer plate (kutub + ). Sisiran dilepas dan sumuran dibersihkan dengan syringe. Sampel Protein 100 kDa ditambah loading buffer 1:1 diinjeksikan ke dalam sumuran. Running dilakukan pada 2 tahap constan voltage yaitu pertama constan voltage $150 \mathrm{~V}$ selama 30 menit dan kedua constan voltage $200 \mathrm{~V}$ selama 1,5 jam.

\section{Fixing}

Menuangkan masing-masing running buffer (Chatolyte dan anolyt) pada tempat yang berbeda. Gel diambil dan diletakkan pada wadah yang berisi TCA $10 \%$, rendam selama 10 menit. Setelah 10 menit larutan dibuang dan rendam gel dalam TCA $1 \%$ selama 2 jam sampai semalam.

\section{Staining dan Destaining}

Gel hasil fixing direndam dalam larutan staining sambil digoyang selama 30 menit. Kemudian dicuci dengan $150 \mathrm{~mL}$ asam asetat yang direndam dalam larutan destaining selama 30 menit sambil digoyang. Selanjutnya dicuci dengan asam asetat sampai bening. Perlakuan di atas menggunakan penggoyang otomatis (shaker).

\section{Mengukur Kadar Protein dengan Metode Biuret}

Penentuan Panjang Gelombang Maksimum BSA 5000 ppm. Sebanyak $200 \mu \mathrm{L}$ larutan standar Bovine Serum Albumin (BSA) konsentrasi 5000 ppm dimasukkan ke dalam eppendorf, ditambah dengan $800 \mu \mathrm{L}$ reagen Biuret, kemudian dikocok 
dan didiamkan selama 30 menit. Selanjutnya diukur serapannya menggunakan spektrofotometer UV-VIS pada kisaran panjang gelombang 500-600 nm. Sebagai blanko dipipet $200 \mu \mathrm{L}$ akuades dan $800 \mu \mathrm{L}$ reagen Biuret.

\section{Pembuatan Kurva Standar BSA}

Disiapkan 10 eppendorf, masing-masing ditambah dengan $200 \mu \mathrm{L}$ larutan standar BSA (Bovine Serum Albumin) dengan variasi konsentrasi 100-10.000 ppm. Masing-masing ditambah dengan $800 \mu \mathrm{L}$ reagen Biuret. Kemudian dikocok dan didiamkan selama 30 menit pada suhu kamar. Selanjutnya diukur serapannya dengan spektrofotometer UV-VIS pada $\lambda$ maksimum yang diperoleh dari pengukuran larutan standar BSA 5000 ppm. Kemudian dibuat persamaan regresi linier hubungan antara konsentrasi dan absorbansi sehingga diperoleh kurva standar BSA.

\section{Pengukuran Kandungan Protein 100 kDa}

Diambil $200 \mu \mathrm{L}$ sampel Protein 100 kDa, ditambah $800 \mu \mathrm{L}$ reagen Biuret kemudian dikocok dan didiamkan selama 30 menit pada suhu kamar. Selanjutnya diukur serapannya dengan spektrofotometer UV-VIS pada $\lambda$ maksimum yang diperoleh dari pengukuran larutan standar BSA 5000 ppm. Sebagai blanko dipipet $200 \mu \mathrm{L}$ air dan ditambah dengan $800 \mu \mathrm{L}$ reagen Biuret dikocok dan didiamkan selama 30 menit pada suhu kamar selanjutnya diukur serapannya dan diulangi 3 kali.

Kandungan protein diperoleh dengan cara mengkonversi data dan absorbansi ke konsentrasi melalui persamaan regresi linier kurva standar BSA, menurut Hamilton [8] menggunakan rumus:

$$
\begin{aligned}
& Y=a . X \\
& X=\frac{Y}{A}
\end{aligned}
$$

Dimana $X=$ konsentrasi total protein

\section{Analisis Data}

Data yang telah diperoleh dari hasil perlakukan dianalisis secara deskriptif.

\section{HASIL DAN PEMBAHASAN Kualitas Semen Segar Kambing}

Pemeriksaan semen segar dilakukan secara secara makroskopis dan mikroskopis segera setelah proses penampungan semen dilakukan. Pemeriksaan makroskopis meliputi pemeriksaan warna, volume, konsistensi dan $\mathrm{pH}$, sedangkan pemeriksaan secara mikroskopis meliputi konsentrasi, persentase hidup, motilitas massa dan motilitas individu. Hasil pemeriksaan semen segar yang digunakan dalam penelitian ini menunjukkan kualitas semen yang normal seperti yang ditunjukkan dalam Tabel 2 .

Tabel 2. Hasil Pemeriksaan Semen Segar Kambing Percobaan

\begin{tabular}{lll}
\hline \multicolumn{1}{c}{ Parameter } & Standar Semen Normal & Rata-rata \pm SD \\
\hline Volume (ml/ejakulat) & $0,5-2$ & $0,90 \pm 0,25$ \\
\hline Warna & Krem-putih kekuningan & Krem \\
\hline $\mathrm{pH}$ & $6,9-7,5$ & 7 \\
\hline Konsistensi & Kental & Kental \\
\hline Motilitas Massa & $2+-3+$ & $2+$ \\
\hline Motilitas individu (\%) & $60-90$ & $70 \pm 0,25$ \\
\hline Persentase hidup (\%) & $\geq 70$ & $80,44 \pm 0,35$ \\
\hline Konsentrasi (juta/ml) & $1500-5000$ & $2560 \pm 257,10$ \\
\hline
\end{tabular}

Berdasarkan hasil pemeriksaan terhadap beberapa parameter di atas dapat diketahui bahwa kualitas dan kuantitas semen kambing yang digunakan dalam penelitian ini baik.

\section{Berat Molekul Protein 100 kDa}

Berat molekul isolat protein membran spermatozoa kambing ditentukan dengan mengeplotkan harga $\mathrm{Rf}$ yang diperoleh pada persamaan regresi linier $Y=-2,1378 X+5,5952$ kurva hubungan antara $\mathrm{Rf}$ (sumbu $\mathrm{X}$ ) dengan log BM protein standar (sumbu $Y$ ) sehingga diperoleh pita protein yang terdiri atas 7 pita dengan berat molekul 166,7; 122; 100; 82,8; 60,4; 29,9 dan 14,8 kDa (Gambar 1).

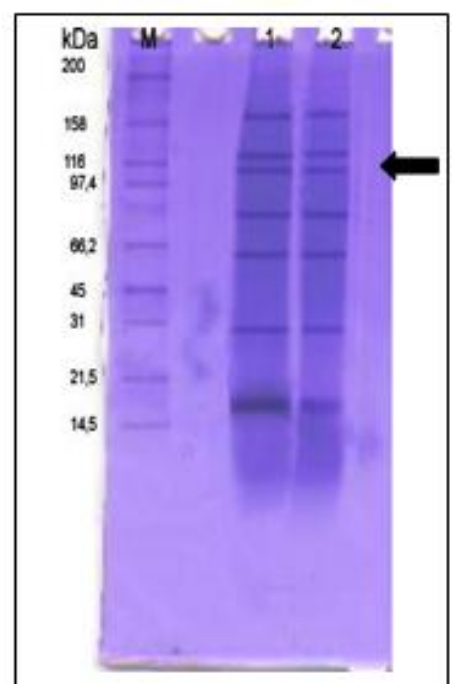

Gambar 1. Elektroforegram Protein 100 kDa Keterangan: $\mathrm{M}=$ Marker; 1,2 = Sampe; $\rightarrow=\mathrm{BM}$ Protein $100 \mathrm{kDa}$

Untuk memperoleh isolat Protein 100 kDa maka dilakukan purifikasi menggunakan metode elektroelusi dengan cara memotong pita dengan BM 100 kDa dan dilakukan elusi selama semalam. 
Hasil elusi Protein 100 kDa terlihat pada Gambar 2.

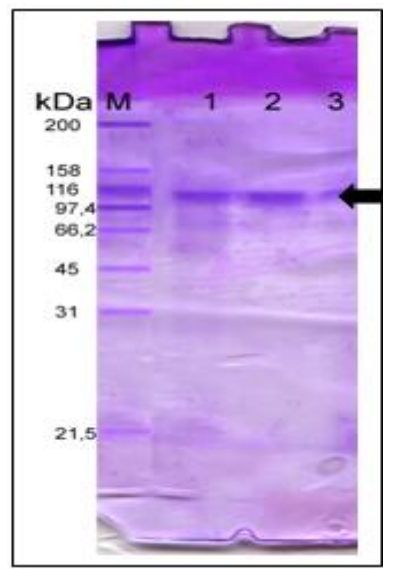

Gambar 2. Hasil elusi Protein $100 \mathrm{kDa}$

Keterangan: $\mathrm{M}=$ Marker; $1,2=$ Sampe; $\rightarrow=$ BM Protein $100 \mathrm{kDa}$

\section{Titik Isoelektrik Protein $\mathbf{1 0 0 ~ k D a}$}

Isoelectric Focusing (IEF) gel elektroforesis adalah teknik untuk memisahkan protein pada muatan bersihnya (tanpa/titik isoelektrik). Pemisahan protein berdasarkan gradien $\mathrm{pH}$ pada muatan listriknya (electric field). Pada kondisi ini, protein bermigrasi sampai posisi gradien pHnya tidak bermuatan atau titik isoelektriknya nol (zero) [9].

Hasil IEF gel elektroforesis Protein 100 kDa dari membran spermatozoa kambing yang diejakulasikan ini mempunyai tiga titik isoelektrik yaitu 6,37; 6,05 dan 5,64. Hasil tersebut hampir sama dengan hasil Isoelectric Focusing dari protein MPS ecto CIK yang berasal dari membran spermatozoa di cauda epididimis kambing yang ditemukan Maiti et al. [2] yaitu 6,37; 6,05 dan 5,14 . Hasil IEF Protein $100 \mathrm{kDa}$ pada penelitian ini tampak pada Gambar 3.

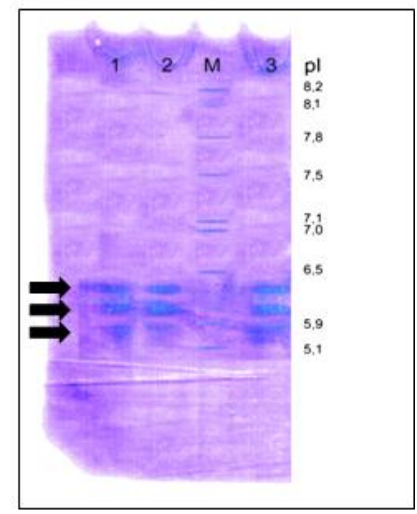

Gambar 3. Hasil IEF gel elektroforesis Protein $100 \mathrm{kDa}$ Keterangan: $M$ =Marker Protein; $1,2,3$ = Sampel; $\rightarrow=$ tiga titik isoelektrik ( $p l$ ) protein $100 \mathrm{kDa}$ yaitu: 6,37; 6,05 dan 5,64.

\section{Kandungan Protein 100 kDa}

Pada penelitian ini dilakukan analisis terhadap kandungan protein isolat Protein 100 kDa dengan metode Biuret. Hasil analisis data dapat dilihat pada Tabel 3.

Tabel 3. Karakter Biokimia Protein 100 kDa dari membran Spermatozoa Kambing

\begin{tabular}{|lc|}
\hline $\begin{array}{l}\text { Rataan Kandungan dalam Isolat } \\
\text { Protein } 100 \mathrm{kDa}\end{array}$ & Isolat Protein $100 \mathrm{kDa}$ \\
\hline Protein $(\mu \mathrm{g} / \mathrm{mL})$ & $2375 \pm 5,65$ \\
\hline
\end{tabular}

Kandungan protein dalam isolat Protein 100 $\mathrm{kDa}$ ditentukan dengan mengkonversikan serapan pada kurva Bovine Serum Albumin (BSA) yang sudah diketahui konsentrasinya. Dari hasil penelitian dan analisis pada persamaan $Y=5.10^{-5}$ $X$, diperoleh kandungan rata-rata protein total isolat Protein $100 \mathrm{kDa}$ sebesar $2375 \pm 5,65$ $\mu \mathrm{g} / \mathrm{mL}$.

Berdasarkan hasil yang telah diperoleh menunjukkan bahwa isolat Protein 100 kDa dapat digunakan sebagai imunogen. Syarat minimal penggunaan protein sebagai antigen adalah sebesar $300 \mu \mathrm{g} / 200 \mathrm{ml}$ pelarut [10].

\section{Kesimpulan}

Berdasarkan hasil penelitian dan pembahasan yang diuraikan di atas maka dapat diambil kesimpulan bahwa karakter biokimia Protein 100 kDa dari membran spermatozoa kambing yang sudah diejakulasikan yaitu mempunyai berat molekul $100 \mathrm{kDa}$ dengan tiga titik isoelektrik yaitu 6,37; 6,05 dan 5,64 dan rata-rata kandungan protein total dari isolat sebesar 2375 $\pm 5,65 \mu \mathrm{g} / \mathrm{mL}$.

\section{Saran}

Perlu dilakukan penelitian lebih lanjut untuk mengetahui kemampuan Protein 100 kDa membran spermatozoa kambing yang sudah diejakulasikan dalam menginduksi respon imun humoral.

\section{DAFTAR PUSTAKA}

[1] Mitra S. and Majumder G.C. 1991. Alteration of the Ecto-protein phosphorilation profile of intact goat Spermatozoa during Epididymal Maturation. Biochem Int., 23 (3): 611-618.

[2] Maiti A., Mishra K.P. and Majumder G.C. 2004. J. of Cell. Biochem., 92:164-177.

[3] Subowo. 1993. Imunobiologi. Angkasa. Bandung

[4] Partodihardjo S.W. 1992. IImu Reproduksi Ternak. Mutiara Sumber Widya. Jakarta. 
[5] Jayendran R.S., H. H. Van der van and PerzPelaez M. 1984. Development of an assay to access the functional integrity of the human sperm membrane.

[6] Hinsch E., Oehringer S., Schill W.B and Hinsch K.D. 1999. Specificity of human and murin anti ZP3 Synthetic Peptide Antisera and use of antibodies for localization and Identification of ZP3 or ZPC Domains of Functional Significance. Hum. Reprod. Feb. 14(2): 419-28.

[7] Gatti J.L., Druat X., Syntin P., Guerin Y., Dacheux J.L. and Dacheux F. 2000. Biochemical characterization of two ram cauda epididymical maturation-dependent sperm glycoprotein. Biol. of Reprod., (62): 950-958.

[8] Hamilton D.W. and Gould R.P. 1997. Preelimenary observations on enzymatic galactosylation of glycoproteins on the surface of rat caput epididymal spermatozoa. Int. J. Androl. (suppl.), 5: 7380.

[9] Walker. 1994. Methodes in molecular biology, basic protein and peptide Protocols, 32: 59-67

[10] Robert K. and Peter A. 1993. Harper's biochemistry, $23^{\text {th }}$ edition. Preble hall International Inc., USA. 